\title{
Multi-wavelength Raman lidar observations of the Eyjafjallajökull volcanic cloud over Potenza, southern Italy
}

\author{
L. Mona, A. Amodeo, G. D’Amico, A. Giunta, F. Madonna, and G. Pappalardo \\ Consiglio Nazionale delle Ricerche - Istituto di Metodologie per l'Analisi Ambientale (CNR-IMAA), C.da S. Loja, \\ 85050 Tito Scalo, Potenza, Italy
}

Correspondence to: L. Mona (mona@imaa.cnr.it)

Received: 15 March 2011 - Published in Atmos. Chem. Phys. Discuss.: 26 April 2011

Revised: 20 January 2012 - Accepted: 18 February 2012 - Published: 29 February 2012

\begin{abstract}
During the eruption of Eyjafjallajökull in AprilMay 2010 multi-wavelength Raman lidar measurements were performed at the CNR-IMAA Atmospheric Observatory (CIAO), whenever weather conditions permitted observations. A methodology both for volcanic layer identification and accurate aerosol typing has been developed. This methodology relies on the multi-wavelength Raman lidar measurements and the support of long-term lidar measurements performed at CIAO since 2000. The aerosol mask for lidar measurements performed at CIAO during the $2010 \mathrm{Ey}-$ jafjallajökull eruption has been obtained. Volcanic aerosol layers were observed in different periods: 19-22 April, 2729 April, 8-9 May, 13-14 May and 18-19 May. A maximum aerosol optical depth of about $0.12-0.13$ was observed on 20 April, 22:00 UTC and 13 May, 20:30 UTC. Volcanic particles were detected at low altitudes, in the free troposphere and in the upper troposphere. Occurrences of volcanic particles within the PBL were detected on 21-22 April and 13 May. A Saharan dust event was observed on 13-14 May: dust and volcanic particles were simultaneously detected at CIAO at separated different altitudes as well as mixed within the same layer.

Lidar ratios at 355 and $532 \mathrm{~nm}$, the Ångström exponent at $355 / 532 \mathrm{~nm}$, the backscatter-related Ångström exponent at $532 / 1064 \mathrm{~nm}$ and the particle linear depolarization ratio at $532 \mathrm{~nm}$ measured inside the detected volcanic layers are discussed. The dependence of these quantities on relative humidity has been investigated by using co-located microwave profiler measurements. The measured values of these intensive parameters indicate the presence of volcanic sulfates/continental mixed aerosol in the volcanic aerosol layers observed at CIAO. In correspondence of the maxima ob-
\end{abstract}

served in the volcanic aerosol load on 19-20 April and 13 May, different values of intensive parameters were observed. Apart from the occurrence of sulfate aerosol, these values indicate also the presence of some ash which is affected by the aging during transport over Europe.

\section{Introduction}

Eyjafjallajökull, a small volcano under Iceland's ice cap, entered an explosive eruptive phase on 14 April 2010 after an effusive period of approximately 6 weeks. This mediumsized eruption (Petersen, 2010) caused an enormous disruption to air traffic across western and northern Europe, because it injected ash directly into the Jet Stream and from there in the northern Europe free troposphere. The explosive eruptive activity lasted until 21 May 2010 with variable intensity, emission of material and plume height (Langmann et al., 2012).

After Eyjafjallajökull's first explosive eruption on 14 April 2010 the aerosol scientific community focused on the observation of the volcanic cloud. EARLINET, the European Aerosol Research Lidar NETwork, performed almost continuous measurements since 15 April 2010 in order to record the evolution of the volcanic cloud generated from the eruption. EARLINET measurements were performed according to the alerts distributed by CNR-IMAA based on the model calculations of the ash dispersion provided by VAAC (Volcanic Ash Advisory Center) and EURAD (EURopean Air Pollution Dispersion). Between 15 April-26 May, the volcanic cloud was transported to different regions of continental Europe at different altitudes depending on the prevailing wind 
direction. The concentration of volcanic particles widely varied over the different regions affected during this 1-month lasting event. Volcanic particles were observed in the UK, Ireland, Germany and France from very low altitudes up to the upper troposphere throughout most of 2010 Eyjafjallajökull eruptive period (e.g. Pappalardo et al., 2010a; Schumann et al., 2011; Campanelli et al., 2012; Dacre et al., 2011; O'Dowd et al., 2012; Ansmann et al., 2011; Hervo et al., 2012; Matthias et al., 2012). The cloud was also observed over Switzerland, Poland and Norway (Bukowiecki et al., 2011; Markowicz et al., 2012; Campanelli et al., 2012; Schumann et al., 2011). The cloud reached Italy and Greece starting from 19-20 April, after passing the Alps (Pappalardo et al., 2010a; Lettino et al., 2011; Campanelli et al., 2012; Papayannis et al., 2012). In May 2010, the volcanic cloud was transported over the Iberian Peninsula (Toledano et al., 2012) and then moved towards the East, reaching Italy, Greece and Turkey (Pappalardo et al., 2010a; Papayannis et al., 2012).

Many detailed studies based on remote sensing observations published in the peer-reviewed literature provide a characterization of the large amount of volcanic particles observed over Central Europe during the volcanic event (e.g. Ansmann et al., 2011; Flentje et al., 2010; Emeis et al., 2011; Gasteiger et al., 2011; Schumann et al., 2011). As mentioned above, some papers reporting the observations of Eyjafjallajökull volcanic cloud in southern Europe (e.g. Lettino et al., 2011; Campanelli et al., 2012; Papayannis et al., 2012; Toledano et al., 2012) have recently appeared in the literature. The arrival of the volcanic cloud in the Mediterranean region is particularly interesting for several reasons. Firstly, the observations at locations far away from the source allow us to investigate modification in aerosol properties occurred during the transport as well as mixing processes across the European continent. In particular, Saharan dust occurrences in southern Europe are typical in spring and summer, thus offering an opportunity to study both the differences and mixing of volcanic aerosols with desert dust particles. Secondly, the large distance from the volcano and the low amount of aerosols reaching this area make the observations of the volcanic cloud in Mediterranean regions useful for the evaluation of different models (e.g. Matthias et al., 2012; Stohl et al., 2011) at the extremes of their applicability, i.e. for low aerosol concentration and at large distances from the emitting source. Finally, it is worth considering that the volcanic plume over southern Europe, even though less intense than in Central and northern Europe, could affect the Mediterranean ecosystem given that the Mediterranean Sea is an almost closed basin.

In this paper, we are presenting and discussing the observations made in the context of the Eyjafjallajökull volcanic eruption performed at CNR-IMAA, Potenza, southern Italy $\left(40^{\circ} 36^{\prime} \mathrm{N}, 15^{\circ} 44^{\prime} \mathrm{E}, 760 \mathrm{~m}\right.$ above sea level).

CNR-IMAA is an EARLINET core station due to its longterm observations (it has been participating in the network since its establishment in 2000) and its multi-wavelength
Raman lidars. CNR-IMAA runs an advanced observatory, named CIAO (CNR-IMAA Atmospheric Observatory), equipped with state-of-the-art instruments for the groundbased remote sensing of aerosol, water vapour and clouds (Madonna et al., 2011). The first Raman lidar measurements of volcanic aerosol in the troposphere were performed at CNR-IMAA during the 2002 volcanic eruption of Etna (Pappalardo et al., 2004a). These observations were subject of a detailed study based on an approach of combining lidar observations with transport models (Villani et al., 2006). Based on the expertise at CIAO and the local database of long-term lidar observations, a methodology for identifying volcanic aerosol layers in the vertical backscatter profile time-series was developed. It is widely known that lidar measurements are particularly effective for the near-real time observation of high aerosol contents, however, the reliable and quantitative identification of layers, cloud screening and aerosol characterization are still non-trivial aspects in data retrieval. There are different automated analysis methods, such as that used for the CALIPSO mission (Liu et al., 2010), which aim at providing reliable results in near-real time. The corresponding algorithms rely on the idea that the entire range of optical properties have already been measured and characterized for each aerosol class. Therefore, these algorithms are not appropriate for particular scenarios such as tropospheric volcanic clouds because of the specificity of each volcanic eruption and the overall scarcity of observations related to this kind of event. In contrast, the multi-wavelength Raman lidar has been widely proved to be an effective tool for aerosol characterization as well as for the investigation of the modification processes that occur during the transport and the mixing of different aerosol types (e.g. Müller et al., 2007; Papayannis et al., 2008). Moreover, it has been shown that a careful analysis based on lidar observations, air-mass backtrajectories and modeling tools is needed for a detailed classification of the observed aerosols (e.g. Mona et al., 2006b; Müller et al., 2009; Villani et al., 2006; Pappalardo et al., 2010c).

After a short description of the lidar measurements performed at CIAO during the Eyjafjallajökull eruptive period, the methodology for aerosol masking is described in Sect. 3. The aerosol masks for the observations collected between 15 April and 20 May 2010 are reported in Sect. 4 together with results on optical properties of aerosol that were identified as being of volcanic origin. The final section summarizes this publication.

\section{Lidar measurements}

The current study mainly relies on lidar measurements performed by PEARL (Potenza EArlinet Raman Lidar), the multi-wavelength lidar system for tropospheric aerosol characterization designed and operated by CNR-IMAA since $\mathrm{Au}-$ gust 2005 (Mona et al., 2009). This system is an upgrade of a pre-existing Raman lidar system for tropospheric aerosol 
studies which has been operative since the year 2000 (Mona et al., 2006b). PEARL measures the radiation elastically backscattered from the atmosphere at three laser wavelengths ( $355 \mathrm{~nm}, 532 \mathrm{~nm}$ and $1064 \mathrm{~nm}$ ), the $\mathrm{N}_{2}$-Raman shifted radiation backscattered at $387 \mathrm{~nm}$ and $607 \mathrm{~nm}$, and the perpendicular and the parallel polarized components of the $532 \mathrm{~nm}$ backscattered light (with respect to the linearly polarized laser beam direction). Simultaneous aerosol extinction and backscatter profiles at 355 and $532 \mathrm{~nm}$ are retrieved with the combined elastic-Raman retrieval (Ansmann et al., 1992). This allows the direct measurement of lidar ratio (extinctionto-backscatter ratio) vertical profiles at 355 and $532 \mathrm{~nm}$. Additionally, the aerosol backscatter at $1064 \mathrm{~nm}$ is retrieved through an iterative procedure (Di Girolamo et al., 1999), with a lidar ratio profile selected on the basis of the lidar ratio profiles measured at 355 and $532 \mathrm{~nm}$. Summarizing, aerosol backscatter coefficient profiles at 3 wavelengths $(355,532$ and $1064 \mathrm{~nm})$ and extinction profiles at 2 wavelengths (355 and $532 \mathrm{~nm}$ ) are simultaneously measured at CIAO. This set of measurements will be referred to as " $3+2$ " measurement in the following. The particle linear depolarization ratio profile at $532 \mathrm{~nm}$ is retrieved by using the " $0^{\circ}$-calibration" technique as described in Freudenthaler et al. (2009). More technical details of the PEARL set-up and the retrieved products can be found in Madonna et al. (2011) and Mona et al. (2009).

According to the EARLINET observational strategy established for this volcanic eruption event (Pappalardo et al., 2010b), lidar measurements were performed at CIAO from 15 April until 20 May during alert periods, whenever weather conditions permitted same. Two distinct phases of volcaniccloud transport over Europe were observed (Pappalardo et al., 2010a): 15-30 April, when wind transported the emitted material over Central Europe and then towards the SouthSoutheast; after 5 May, when most of the Eyjafjallajökull volcano emissions were transported immediately into western Europe and subsequently towards Italy, the Balkans and Greece.

From 15 April, lidar measurements were performed at CIAO whenever low clouds and rain were absent. The arrival of volcanic ash over northern and Central Europe was forecast for the period from 19-22 April with some feeble transport of ash beyond the Alps in a more southerly direction. During 25-30 April desert dust arrived over southern Europe followed by a change in the wind direction with air masses coming from north-eastern Europe, transporting material emitted by Eyjafjallajökull over western Europe and then over Italy and Greece. This situation lasted for the following days, while Saharan dust also occurred over southern Europe. A possible arrival of volcanic cloud over northern Italy was forecast for 8 May. Accordingly, lidar measurements were performed from 8 May, 20:00 UTC to 11 May, 02:00 UTC. CIAO ran lidar measurements from 12 May, 12:00 UTC, to 15 May, 01:00 UTC, when rainfall caused observations to be stopped. The last measurements performed for the Eyjafjallajökull volcano eruption started on 18 May, 06:00 UTC, and continued until 19 May, 11:00 UTC.

Quick-looks of time series of elastic backscatter lidar data were made available in near-real time on the CNR-IMAA web site (www.imaa.cnr.it) in order to meet the national and international demand for information on the volcanic cloud behavior. A link to the EARLINET quick-look web-site (www.earlinet.org) allowed an easy and fast overview of the aerosol layers over Europe during the entire period. In addition, a daily report of EARLINET volcanic cloud observations was available at EARLINET web-site summarizing relevant information on the volcanic cloud over Europe. A preliminary quick analysis of CIAO data showed 5 periods potentially affected by the arrival of volcanic particles: 1922 April, 27-29 April, 8-10 May, 12-14 May and 18-19 May.

\section{Methodology}

A big effort was made at CIAO to collect the largest possible database of volcanic-related lidar observations. Periods of volcanic material being potentially present over Italy were identified by a preliminary near-real time inspection of the data. A detailed analysis is needed to investigate the time and range-resolved occurrences of volcanic aerosol, especially for a lidar station located far away from the volcano, where the amount of volcanic aerosol is much lower than that observed in Central Europe (e.g. Schumann et al., 2011; Ansmann et al., 2010; Gasteiger et al., 2010), and in a period in which Saharan dust occurrences are often observed in southern Europe.

In this context an appropriate methodology has been developed consisting of the following steps: (i) the identification of particle layers; (ii) cloud versus aerosol discrimination (iii) aerosol typing through the investigation of intensive properties measured by multi-wavelength Raman lidar, models and back-trajectory analysis.

This methodology permits to obtain a quantitative and reliable aerosol mask that is going beyond the qualitative layering information provided by the temporal evolution of the range-corrected lidar signal provided in near-real-time during the volcanic event. As an example Fig. 1 reports the temporal evolution of the range-corrected lidar signal measured at $1064 \mathrm{~nm}$ at CIAO in the period 12-14 May. This figure illustrates the effectiveness of lidar measurements for determining atmospheric layering. The signature of a strong $1-1.5 \mathrm{~km}$-deep particle layer decreasing in altitude from 5 to $3 \mathrm{~km}$ a.s.l. is evident at the beginning of the time series. On 13 May early morning, the arrival of a tenuous layer is distinguishable at $6 \mathrm{~km}$. This layer is descending in the following hours and becomes a dense but very thin layer located around $2-2.5 \mathrm{~km}$ from the evening of 13 May until the early morning of 14 May. Frequent, short, and intense lidar backscatter signals are evident below $2 \mathrm{~km}$ between 13 May, 12:00 UTC, 


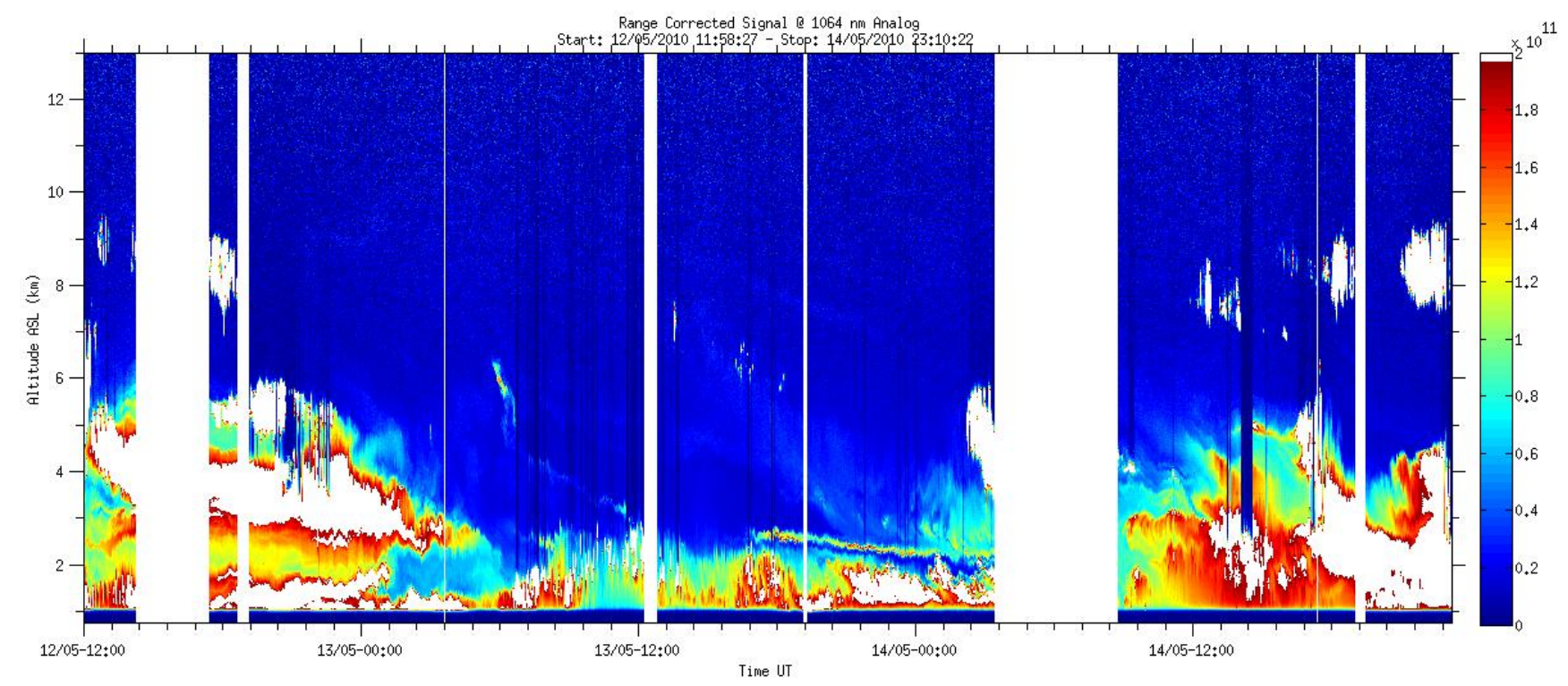

Fig. 1. Temporal evolution of the range corrected lidar signal measured at $1064 \mathrm{~nm}$ in the period $12-14$ May by PEARL at CIAO. The vertical and temporal resolutions are $7.5 \mathrm{~m}$ and $30 \mathrm{~s}$, respectively.

and 14 May, 04:00 UTC, when measurements were interrupted because of low clouds and light rain. Aerosol layers were present up to $6 \mathrm{~km}$ on 14 May from 09:00 UTC to 23:00 UTC, when low clouds followed by intense rain forced the measurement stop.

\subsection{Layer identification}

An algorithm has been implemented for the quantitative identification of layers above the PBL. The main concept is that layer features can be identified through the first derivative of the particle backscatter profile. Other methods are reported in the literature (e.g. Steyn et al., 1999; Wang and Sassen, 2008), however, the results obtained by using all these methods typically agree within the experimental errors. With respect to the procedures commonly used for aerosol/cloud identification (e.g. Morille et al., 2007; Vaughan et al., 2004), the advantage of our approach is that of using calibrated backscatter profiles whose high quality is certified by the EARLINET quality assurance program (Böckmann et al., 2004; Pappalardo et al., 2004b), rather than range-corrected signals. This makes it possible to overcome problems related to the normalization processes applied in automated methods based on range-corrected signals.

However, since the derivative is highly sensitive to fluctuations, a smoothing procedure is typically needed. A secondorder Savitsky-Golay filter is applied on the differential because of its effectiveness in preserving vertical structures (Pappalardo et al., 2004b). The number of points is progressively increased as the signal noise increases, with $1000 \mathrm{~m}$ as fixed maximum of the effective vertical resolution (Pappalardo et al., 2004b).

This method for the identification of layers can be applied only in regions where the relative statistical error on backscatter profiles is sufficiently low. Tests performed on several EARLINET station data identified $30 \%$ as a reasonable error limit for the application of the derivative method. In the altitude region characterized by a relative error on the aerosol backscatter coefficient higher than $30 \%$, layers are identified as those regions where the scattering ratio (i.e. the total to molecular backscatter ratio) is higher than a predefined threshold. In particular, particle layers should correspond to a scattering ratio significantly higher than the value observed for aerosol background conditions. The scattering ratio background value is evaluated in the $6.5-8.5 \mathrm{~km}$ altitude range, which is typically not affected by an significant particle transport, on the basis of the long-term aerosol observations performed at CIAO since 2000. Particle layers are identified as altitude regions where the scattering ratio is higher than the defined threshold plus the scattering ratio absolute statistical error.

The layer identification is performed above the top altitude of the PBL which is calculated by using the procedure established within EARLINET (Matthias et al., 2004). In this way, layers consisting of transported aerosols (like Saharan dust and volcanic aerosol) can be identified. The penetration of particles into the PBL from higher layers would lead to a mixing of local aerosol (typically confined in the PBL) with transported aerosol. These situations will be identified on the basis of the temporal evolution of the layers and modification of aerosol optical properties in the PBL region. 
Finally, in order to only include reliable information in the aerosol mask, only the altitude ranges where the statistical error on backscatter coefficient is lower than $50 \%$ are considered in this spatio-temporal evolution study.

A compromise between the high temporal resolution and a longer time average for reducing the statistical error is necessary. A temporal average of $1 \mathrm{~h}$ is chosen in order to be able to draw direct comparisons with models that typically provide data every hour (e.g. Matthias et al., 2012).

The aerosol backscatter coefficient at $1064 \mathrm{~nm}$ is used for layer identification since the sensitivity to aerosol structures is higher at this wavelength than in the visible or UV. The best possible effective vertical resolution, which is typically $60 \mathrm{~m}$ for the cases under investigation, was chosen each time to minimize the relative error and optimize the vertical profiling capability. The routine for the particle layer identification runs on individual backscatter profiles. As a final step a consistency check is performed on the temporal evolution of the identified layers.

Figure 2 shows an example of single profile particle layer identification, as performed on the aerosol backscatter profile at $1064 \mathrm{~nm}$ measured on 13 May, at 05:30-06:30 UTC. The base and top of each layer are indicated as dotted and solid horizontal lines, respectively. A detailed layering structure characterization is obtained up to the upper troposphere, indicating the presence of an aerosol load higher than what is typically measured at CIAO up to $12 \mathrm{~km}$ a.s.l. The aerosol backscatter gradient analysis (applied below the $30 \%$ error limit, i.e. black trace in Fig. 2) allows us to characterize the internal structure of multi-stratified complex aerosol layers. In the case presented in Fig. 2 five distinct aerosol layers above the top of the PBL are identified up to an altitude of approximately $7 \mathrm{~km}$. At higher altitudes, the applied methodology allows the identification of thin and sparse layers that are exceeding the threshold on the scattering ratio. This is an indication of the presence of a low amount of aerosol at these altitudes. An investigation of the temporal evolution of the layers indicates that these layers are present in subsequent measurements and evolve in time. This permits an objective identification of these features as aerosol layers distinguishable from the measured backscatter profiles.

\subsection{Cloud identification}

After the identification of the particle layers, discrimination between aerosol and cloud is necessary. Cirrus clouds are identified mainly on the basis of their temporal dynamical evolution (Mona et al., 2007), their high particle linear depolarization ratio, and their almost neutral backscatter spectral dependence which is due to the large size of hydrometeors. Following the EARLINET protocol, low clouds are removed before the backscatter profile calculation by eye-inspection of single raw data. The analysis of the temporal evolution of the retrieved aerosol backscatter profile is an additional test for the appropriateness of the low cloud removing procedure.

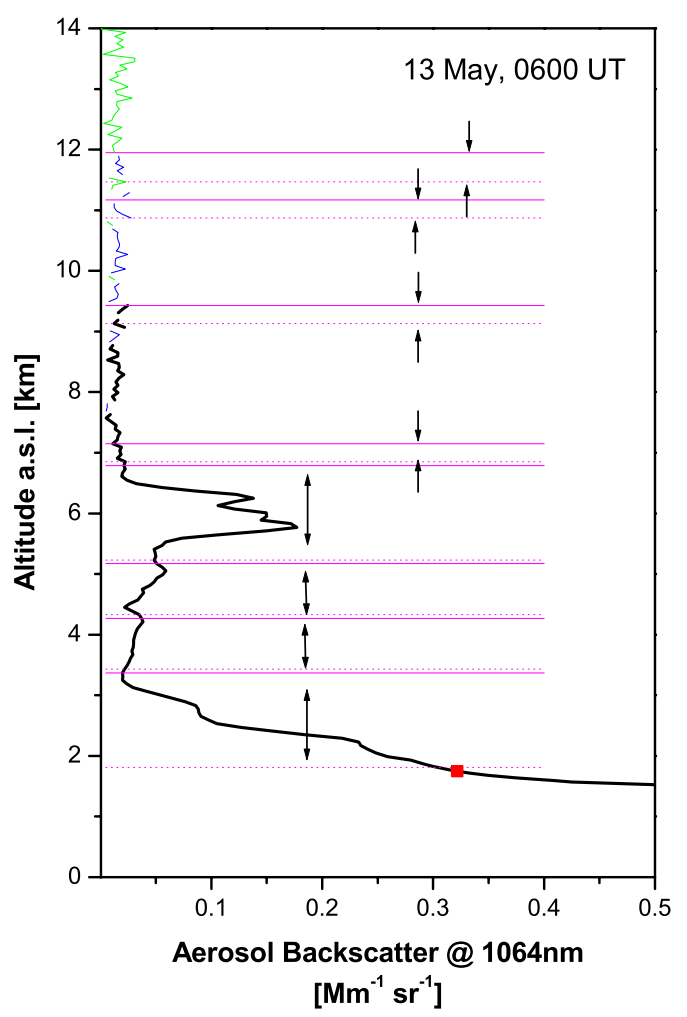

Fig. 2. Example of single profile particle layer identification as performed on the aerosol backscatter profile at $1064 \mathrm{~nm}$ measured on 13 May, at 05:30-06:30 UTC. Horizontal dotted and solid lines indicate the base and top of the identified layers, respectively. The red square indicates the top of the PBL. Region with relative errors between $30 \%$ and $50 \%$ are reported in blue and those with relative error exceeding $50 \%$ in green.

\subsection{Aerosol typing}

Backward trajectory analyses and model outputs are used to investigate the origin and the nature of the aerosol layers identified through the procedure described in Sect. 3.1. In particular, 10-day HYSPLIT backtrajectory analysis provided by NOAA (Draxler and Rolph, 2011) is used because of its large flexibility. Three arrival altitudes can be set by the user and the arrival time can be chosen with a $1 \mathrm{~h}$ resolution. These options make the HYSPLIT backtrajectory analysis very flexible for the aerosol typing in an integrated study with high vertical and temporal resolution lidar data. The use of backtrajectory analysis for the identification of aerosol origin is nowadays well recognized, especially for large-scale sources such as desert regions. Attention should be paid in the presence of highly localized sources, as in the case of volcanic eruptions. For observations performed at long distances from the source and depending on wind speed (Stohl, 1998) the particle position uncertainty increases with increasing trajectory length. For potential volcanic eruption cases, the stability of the aerosol typing is checked by 
slightly changing arrival altitudes and times. The following additional backtrajectory analyses are used to corroborate initial results: (a) 4-day backward trajectories provided by the German Weather Service (DWD) at each EARLINET lidar station for two arrival times per day and six arrival pressures between 200 and $975 \mathrm{hPa}$ (Stohl, 1998). (b) The FLEXTRA trajectory model (Stohl et al., 1995) provided for each EARLINET site every $6 \mathrm{~h}$ at arrival altitudes of 1500, 3000 and $5000 \mathrm{~m}$. (c) The Trajectory Analysis developed by the Atmospheric Chemistry and Dynamics Branch of the NASA/Goddard available for each AERONET site at 00:00 UTC and 12:00 UTC for 8 height pressures between 950 and $200 \mathrm{hPa}$ (Schoeberl and Newman, 1995).

Once the particle path has been identified, the occurrences of a specific event along the path are checked against related models and, where available, satellite data for the identification of the potential aerosol source (for example desert, volcano and fires). In particular, DREAM (Dust REgional Atmospheric Model) forecasts are used for Saharan dust in terms of maps of the dust loading over the Mediterranean Sea and dust concentration profiles over Potenza EARLINET site, both available every $6 \mathrm{~h}$. The Eyjafjallajökull volcanic activity and emission heights are taken into account by using updated reports provided by the Iceland Meteorological Office, VAAC and dedicated studies (e.g. Langmann et al., 2012). Finally, the presence of forest fire episodes is checked by using the World Fire Atlas available at http: //wfaa-dat.esrin.esa.int/, based on the ATSR Active Fire Algorithm.

Special attention should be paid in case of transition between different atmospheric conditions because of the high instability of the backtrajectory analysis in the transient regime between different situations. For such cases, small changes in time (profiles are obtained with $1 \mathrm{~h}$ integration time) and/or altitudes result in big differences in the path of the air mass in the horizontal and vertical direction. The identification of the aerosol layers through the analysis of one wavelength backscatter lidar (Sect. 3.1) and the combined use of models and backtrajectories is not sufficient, and would lead to an undefined aerosol type in the resulting aerosol mask. In this context the single backscatter lidar technique is not sufficient to characterize aerosol, and a reliable identification of the aerosol type is possible only by using multi-wavelength lidar data. Moreover, the long-term lidar measurements performed at CIAO is an added value for the aerosol typing. In particular, intensive properties and their temporal evolution are used here for discriminating different aerosol types such as dust and volcanic particles in uncertain atmospheric situations.

An example of such a situation was evident on 13 May around 05:00 UTC, during a transition from a condition characterized by the presence of dust and volcanic particles, at clearly distinguishable altitudes, to the presence of volcanic particles only.
The profiles of the aerosol backscatter at $1064 \mathrm{~nm}$ for this situation are shown in Fig. 3 together with the backscatterrelated Ångström exponent at 532/1064 nm. On 13 May, at 04:00 UTC, the backscatter-related Ångström exponent at $532 / 1064 \mathrm{~nm}$ (in the following $\stackrel{a}{a}(\beta)$ ) has values ranging between 1.8 and 0.8 between the top of the PBL up to $4 \mathrm{~km}$ a.s.l., with a trend of further decreasing with altitude and a mean value of about 1 in agreement with the results obtained in a multi-year climatological study of Saharan dust intrusions over Potenza (Mona et al., 2006b). The same mean value is found for the 4-6 km altitude range, even though it is characterized by larger oscillations due to a higher statistical error. Therefore, the two identified layers extending between the PBL and $6.4 \mathrm{~km}$ a.s.l. are classified as Saharan dust aerosol layers.

The $\stackrel{a}{a}(\beta)$ profile for 05:00 UTC shows the same dependence on altitude in the $2.1-3.2 \mathrm{~km}$ range with a shift toward lower values with respect to what is measured at 04:00 UTC. Between 3.2 and $6.4 \mathrm{~km}$ a.s.l. the aerosol backscatter profile is different from the previous one, with the presence of 2 layers extending between $3.2-4.9 \mathrm{~km}$ a.s.l. and 5.1-6.4 km a.s.l. For these layers, the mean $\stackrel{a}{a}(\beta)$ value is 0.2 . The significant change in the Ångström exponent indicates the arrival of particles with different properties. According to the air mass backtrajectories these altitudes are likely affected by the volcanic cloud arrival. This indicates a mixing of dust and volcanic particles.

The $\stackrel{\circ}{a}(\beta)$ profile measured at 06:00 UTC, however, exhibits a completely different altitude dependence: $\stackrel{a}{a}(\beta)$ is almost constant (approximately 1), i.e. independent of altitude, indicating a homogeneous layer in terms of aerosol size up to an altitude of $3.4 \mathrm{~km}$ a.s.l. The corresponding backscatter coefficients at 532 and $1064 \mathrm{~nm}$ (see Fig. 2) decrease with altitude, but without pronounced maxima, as is typical for truly mixed situations, indicating a mixing of PBL aerosol and desert dust particles. The feeble feature extending between 3.4 and $4.3 \mathrm{~km}$ a.s.l. is characterized by $\stackrel{\AA}{(}(\beta)$ around 0.2 , which is significantly lower than those observed in dust and in dust/local mixed aerosol, thus indicating the mixing with larger volcanic particles. At higher altitudes (up to $6.8 \mathrm{~km}$ ), the backscatter-related Ångström exponent shows different values (typically close to zero), indicating, for this case, the presence of volcanic aerosol.

This example demonstrates that only advanced lidar observational capability and climatological analysis available at the observational site permit the aerosol typing in complex atmospheric conditions.

\section{Results}

The methodology described in the previous section is applied to all the periods identified as potentially affected by the volcanic cloud accordingly to the preliminary quick analysis of CIAO data: 19-22 April, 27-29 April, 8-9 May, 13-14 May 


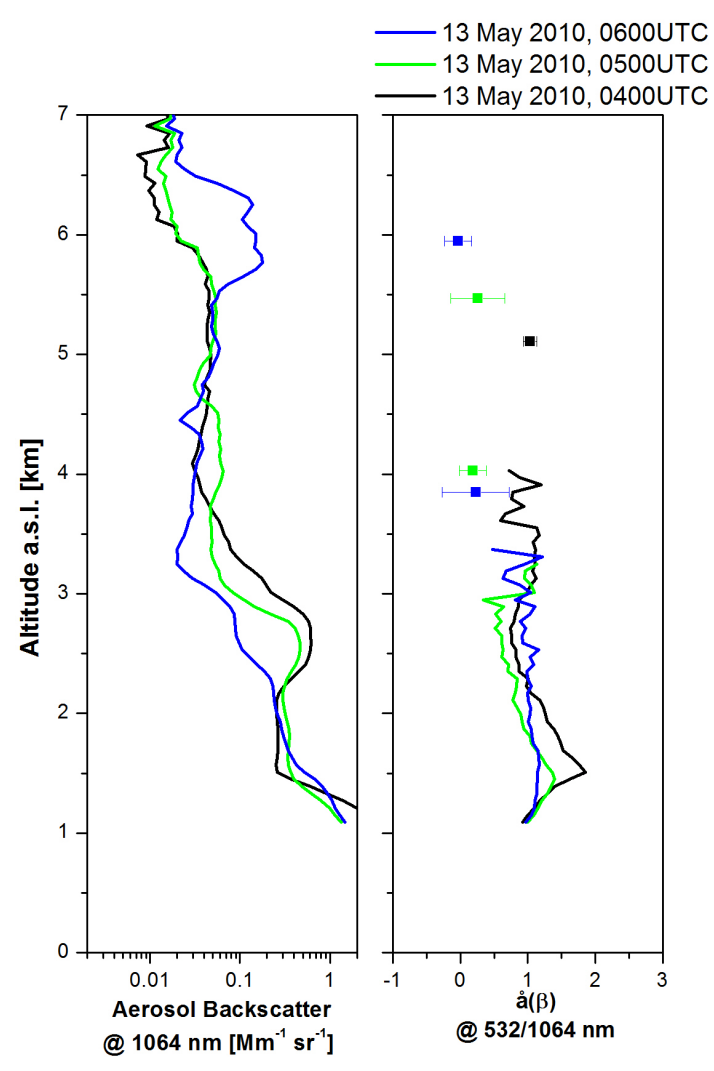

Fig. 3. Profiles of the aerosol backscatter at $1064 \mathrm{~nm}$ and of the backscatter related Ångström exponent at 532/1064 nm measured on 13 May, at 04:00, 05:00 and 06:00 UTC. Mean values are reported as squares for backscatter related Ångström exponent at altitude levels where statistical errors are larger than $30 \%$. Error bars correspond to the standard errors for the mean values.

and 18-19 May. The resulting mask is described in detail for each of these periods, and optical properties are discussed as well. Finally, an overview of the volcanic aerosol optical properties is provided in Sect. 4.2.

\subsection{Aerosol masks}

The result of the aerosol masking is shown in Figs. 4 and 5 , where volcanic aerosol layers are reported in different shades of grey, according to the mean aerosol backscatter at $1064 \mathrm{~nm}$. It should be emphasized again that no distinction between ash particles and smaller no-ash particles (mainly sulfate aerosol) of volcanic origin is made. The grey layers contain both of these components of aerosol, originated by the volcanic eruption and then eventually subject to modifications occurred during the transport across the European continent. PBL aerosols and clouds (and/or cirrus clouds) are reported in yellow and cyan, respectively. Desert dust layers are reported in orange, local-volcanic mixing cases are shown in magenta, and pale orange and pink correspond to local-dust and dust-volcanic mixed aerosols, respectively. If the identification of the origin of particles in a layer was not possible, the corresponding aerosol was classified as unknown (purple).

As reported in the Sect. 3.3, other potential aerosol sources (as forest fires and continental pollution) and correspondingly their potential mixing with volcanic and Saharan dust aerosol were considered. No such cases occurred during the periods under investigation.

\subsubsection{9-22 April 2010}

The first arrival of volcanic particles at CIAO was recorded on 19 April 2010 at 20:00 UTC, when the models considered here did not forecast any other possible source for the observed aerosol layers and the backtrajectories showed air masses coming from Iceland and reaching Potenza. In the period from 19 April, 21:00 UTC, to 20 April, 21:00 UTC, the retrieval of backscatter profiles with a 1-h integration time was inhibited because of low clouds. During daytime a smaller altitude range was investigated in terms of aerosol typing with respect to night-time conditions because of the established limit of $50 \%$ on statistical error.

Gradually descending layers of volcanic particles are observed between 20 April, 21:00 UTC, and 21 April, 12:00 UTC between about $4 \mathrm{~km}$ a.s.l. and the onset of the PBL and at higher altitudes between 10 and $5 \mathrm{~km}$ a.s.l. from 21 April, 00:00 UTC, to 12:00 UTC. This is a typical signature of the arrival of the volcanic cloud observed in different locations in Europe (Flentje et al., 2010; Emeis et al., 2011; Dacre et al., 2011; Hervo et al., 2012; Ansmann et al., 2010). The methodology described in Sect. 3 identified the presence of volcanic particles over the full altitude range studied for the entire measurement period. This wide layer is mainly related to the succession of different explosive and diffusive eruptions as well as the dispersion of the volcanic cloud over the continent. This observation of volcanic aerosol presence over a wide altitude range is in agreement with the widely spread volcanic layers observed in Germany (Ansmann et al., 2011; Emeis et al., 2011) and the dispersion model forecast (Matthias et al., 2012; Heinold et al., 2012). Widely spread layers typically consist mainly of sulfate particles rather than ash. This is particularly true for observation points far away from the aerosol source, like in the case of Potenza. Even though a quantitative distinction between ash and other particles of volcanic origin is beyond the scope of this paper, it is reasonable to assume that the ash component, if present, is only a small percentage of the total volcanic particles detected at CIAO.

A mixing with aerosol in the PBL was observed starting on 21 April, 01:00 UTC, causing an ascent of the top of the PBL to $2.8 \mathrm{~km}$ a.s.l. (i.e. $2 \mathrm{~km}$ above ground level), which is an unusual altitude for night-time observations (Mona et al., 2009). At 10:00 UTC, this $2 \mathrm{~km}$-wide layer splits into two well-defined layers, one between ground level and the top of the PBL at $1.5 \mathrm{~km}$ a.s.1., and the other above the PBL up to about $3 \mathrm{~km}$ a.s.l. The low top altitude of the PBL observed 


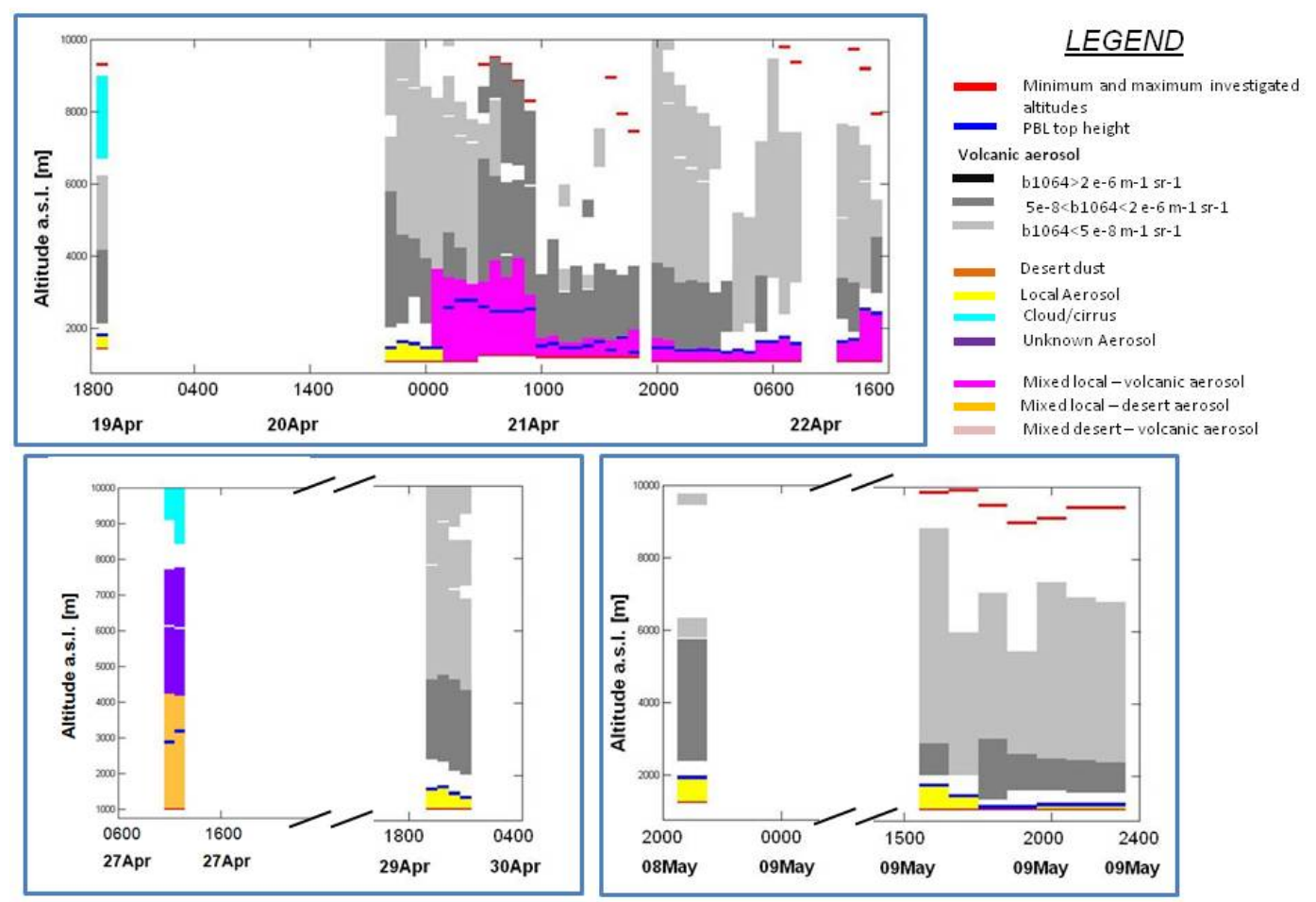

Fig. 4. Aerosol masks for periods 19-22 April, 27-29 April and 8-10 May 2010 in chronological order from the top to the bottom.
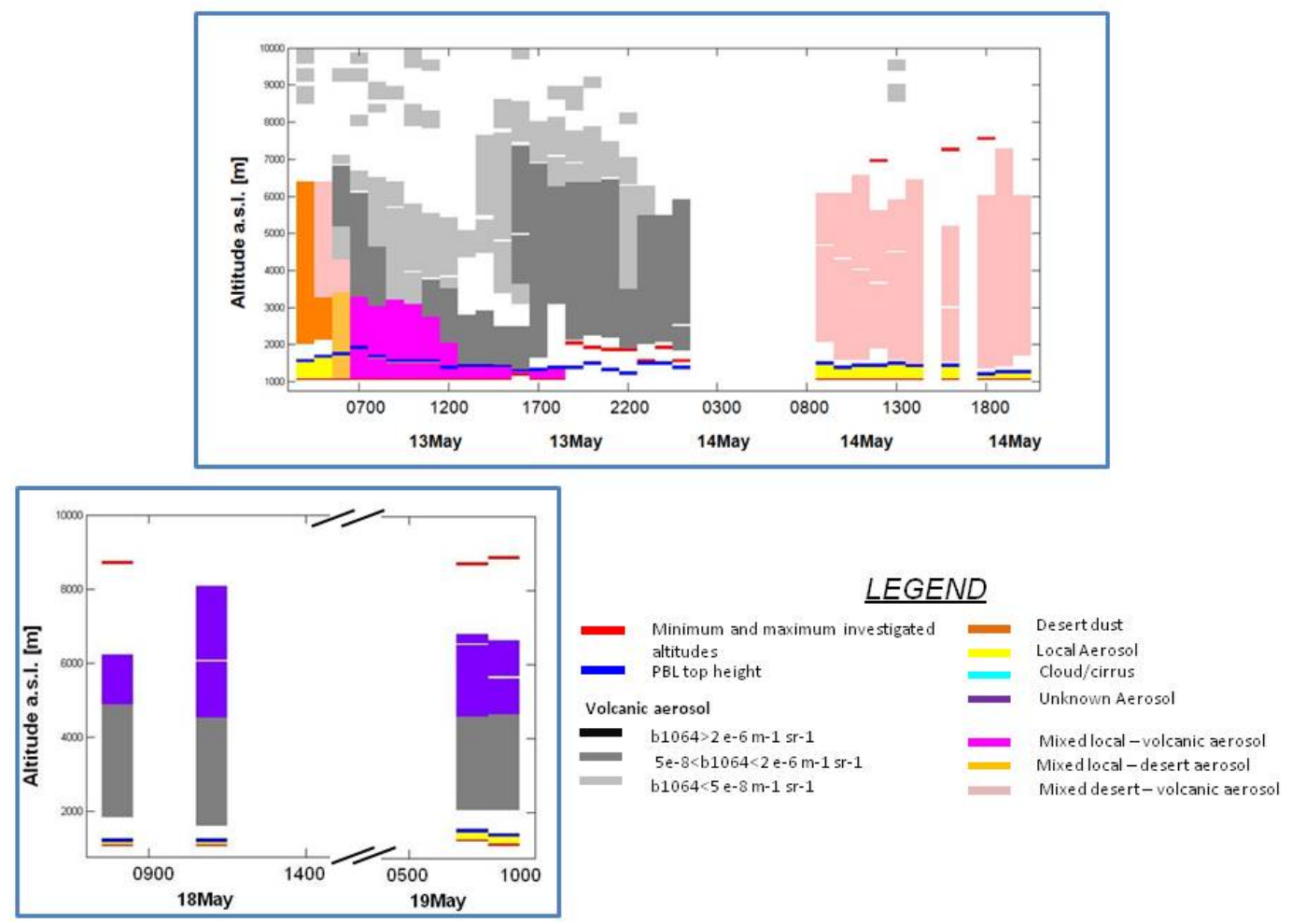

Fig. 5. Aerosol masks for the periods 13-14 May and 18-19 May 2010 displayed in chronological order from the top to the bottom. 
at this time indicates that the mixed aerosols can settle on the ground, in agreement with the detection of volcanic ash and fine particles found by Scanning Electron Microscopy (SEM) in $\mathrm{PM}_{2.5}$ samples that were collected at CIAO during the same period (Lettino et al., 2011). While aerosol settled within the PBL more volcanic particles were still arriving at higher altitudes. Another penetration of aerosol into the PBL was observed at 14:00 UTC, 22 April, when the natural raise of the top of the PBL due to the solar heating results in the mixing of PBL aerosol and volcanic aerosol located just above it.

Complete multi-wavelength analyses for the most significant time-windows were performed when cloud cover permitted: 20 April, 21:00-23:05 UTC and 21 April, 19:06 UTC-22 April, 03:09 UTC (see Table 1 for mean values of intensive parameters calculated within identified layers). In addition, aerosol extinction and backscatter at $355 \mathrm{~nm}$ were available on 19 April, at 19:53-20:36 UTC, together with the aerosol backscatter at $1064 \mathrm{~nm}$. For 19 April, when there was no alert for volcanic particle arrival over Potenza, measurements at $532 \mathrm{~nm}$ were not available. Finally, backscatter-related Ångström exponent at $532 / 1064 \mathrm{~nm}$ were available from diurnal measurements performed on 21 April, at 11:30-12:30 UTC.

A lidar ratio at $355 \mathrm{~nm}$ of $54 \mathrm{sr}$ was observed on the first volcanic cloud arrival (19 April, 19:53-20:24 UTC), in agreement with the values measured at our station for the close-by volcanic event during the 2002 Etna eruption (Pappalardo et al., 2004a) and the Central Europe EARLINET measurements of Eyjafjallajökull volcanic plume (Ansmann et al., 2010). The large standard deviation of this lidar ratio may indicate that the identified layer is not particularly homogeneous in terms of the aerosol microphysical properties, which could be attributed to a small component of volcanic particles with respect to the background ones and the long complex transport path (Villani et al., 2006; Mona et al., 2006a). On 20 April, the maximum peak in the aerosol backscatter at $1064 \mathrm{~nm}\left(3 \times 10^{-7} \mathrm{~m}^{-1} \mathrm{sr}^{-1}\right)$ was observed around 22:00 UTC at about $3.5 \mathrm{~km}$ a.s.1. At the same time, the maximum aerosol optical depth reached a value of 0.13 at $355 \mathrm{~nm}$. Lidar ratios within the identified layers (around 2.5 and $3.5 \mathrm{~km}$ a.s.1.) are around $40 \mathrm{sr}$ and $50 \mathrm{sr}$ at $355 \mathrm{~nm}$ and $532 \mathrm{~nm}$, respectively. The Ångström exponent (available only for the lowest of the 2 layers) of 1.4 indicates the presence of particles which are on average smaller than those observed in Central Europe (Ansmann et al., 2010). Correspondingly, the mean particle linear depolarization ratio at $532 \mathrm{~nm}$ is around $20 \%$, which is significantly lower than the values of around $35 \%$ measured in Germany for this volcanic event (Ansmann et al., 2010). These differences with Leipzig lidar measurements can be due to the longer transport path and a possible contamination with continental aerosols. It is interesting to note the low variability of lidar ratios in this case, which could indicate the microphysical aerosol properties being relatively well-defined and homogeneous.
During 19-22 April an increase in the mean particle size was observed: the backscatter-related Ångström exponent at $532 / 1064 \mathrm{~nm}$ decreased from 1.8 , recorded on 20 April evening, to 1.2 during the night of 21-22 April, passing through 1.3 during daytime measurements on 21 April. Correspondingly, also the Ångström exponent decreased from 1.4 to 1.1 . At the same time the particle linear depolarization ratio slightly increased from $15 \%$ to $25 \%$ in the period 19 22 April, indicating the presence of increasingly aspherical particles.

During the night of 21-22 April, lidar ratios of up to $80 \mathrm{sr}$ at 355 and $532 \mathrm{~nm}$ were observed. These values were larger than those observed in the previous phase for volcanic particles, but are also significantly larger than $37 \mathrm{sr}$ at $355 \mathrm{~nm}$ typically obtained at CIAO (Mona et al., 2006a). The high lidar ratio and the low Ångström exponent might be due to the hygroscopicity of the volcanic particles. This hypothesis is supported by the relative humidity measured at CIAO by the microwave radiometer: in the volcanic aerosols layer, a relative humidity around $20 \%$ was measured on the evening of 20 April, while it was around $50 \%$ on 21 April. In addition, the volcanic layer observed at $1.6-3.4 \mathrm{~km}$ a.s.l. was the result of the splitting of the $2 \mathrm{~km}$-deep PBL: the volcanic aerosol penetrated into the PBL on 21 April, around 01:00 UTC. Subsequently the $2 \mathrm{~km}$-deep PBL separated into 2 well-defined layers, one confined below $1.5 \mathrm{~km}$ and the other extended between 1.6 and $3.4 \mathrm{~km}$ a.s.l. In the light of this, the optical properties of aerosol in the volcanic layer at $1.6-3.4 \mathrm{~km}$ altitude were probably modified due to the mixing with local aerosols.

\subsubsection{7-29 April 2010}

This event was completely different from the previous one in terms of aerosol amount and transport mechanisms. On 23-24 April, it rained almost all day and on 25 April a strong dust event was observed. The unknown aerosol classification was applied for the observation on 27 April. Backtrajectory analysis for the morning of 27 April did not show any clear origin of the air masses. The limited number of hours available for the analysis as well as the availability of only daytime measurements for this day did neither allow us to take advantage of the study of the layer's temporal/vertical evolution nor to utilize the Raman and multi-wavelength data. On 29 April evening, however, there was clear evidence of volcanic particles arriving at CIAO in the entire free troposphere. On this day a peak in the aerosol backscatter coefficient at $1064 \mathrm{~nm}$ of about $2.3 \times 10^{-7} \mathrm{~m}^{-1} \mathrm{sr}^{-1}$ was observed around 22:00 UTC at about $2 \mathrm{~km}$ a.s.l. The complete multiwavelength analysis available for the lowest and most intense aerosol layer (2.7-3.4 km a.s.l.) indicated the presence of smaller volcanic particles with stronger absorption than those observed in northern Europe (Ansmann et al., 2010). 


\subsubsection{8-10 May 2010}

From 5 May wind directions over Europe changed with respect to the previous days, and transported the volcanic cloud almost directly over the Iberian Peninsula and then towards Italy, Greece and the Balkans. Measurements at CIAO started on 8 May in accordance with the plume dispersion forecasts. However, low clouds were present at CIAO until the evening, therefore measurements started only around 20:00 UTC. Volcanic aerosol layers were identified up to $10 \mathrm{~km}$ a.s.l. applying the methodology reported in Sect. 3. In particular, the most intense layer was found at low altitudes just above the top of the PBL. The maximum aerosol backscatter coefficient of about $1 \times 10^{-6} \mathrm{~m}^{-1} \mathrm{sr}^{-1}$ at $1064 \mathrm{~nm}$ was observed at an altitude of ca. $2 \mathrm{~km}$ a.s.l. at 18:00-22:00 UTC. Both the particle linear depolarization ratio and Ångström exponents indicate the presence of volcanic particles that are on average larger and less depolarizing than those observed from the beginning of the night on 22 April; the lidar ratios obtained did, however, not show a significant variation.

\subsubsection{3-14 May 2010}

The scenario observed during this period was characterized by a high variability owing to the presence of both wide and thin intense aerosol layers, cirrus as well as sparse low clouds. Four main situations were observed in the period 13-14 May with transitions from dust intrusion, to altitudedependent mixing of dust and volcanic particles, to a phase completely dominated by volcanic particles back to the arrival of large quantities of dust over a volcanic particle background.

At 04:00 UTC on 13 May, dust and volcanic particles were simultaneously present, but in well distinct layers located at different altitudes. Around 05:00 UTC on 13 May, a significant change in the aerosol transport occurred with air masses coming from north-western Europe, very close to Iceland. Satellite images and ground-based measurements showed the presence of volcanic particles in the corresponding regions (Pappalardo et al., 2010a; Schumann et al., 2011). The analysis of multi-wavelength lidar measurements permitted a detailed aerosol typing. Volcanic layers (at higher altitudes), the mixing of dust and volcanic aerosol (at 05:00 UTC, between 3.2-6.4 km a.s.1. and at 06:00 UTC, between $3.4-4.3 \mathrm{~km}$ a.s.1.), the mixing of dust and local aerosol (at 06:00 UTC below $3.4 \mathrm{~km}$ a.s.1.) and the mixing of volcanic and local particles (between 07:00 UTC and 12:00 UTC, below 3-3.2 km a.s.1.) could be distinguished. The mixing with aerosol in the PBL was observed until the evening of 13 May. The long break in the aerosol mask in the early morning of 14 May was due to the presence of very low clouds and light rain. After this intermission, the mixing of Saharan dust with volcanic particles was observed in the altitude range $2-7 \mathrm{~km}$ a.s.l. in the morning of 14 May. During this time DREAM and backtrajectories analysis showed that, while the transport of volcanic aerosol from Iceland was still ongoing, dust contribution was not negligible.

For the volcanic layer, a maximum aerosol backscatter coefficient of $8 \times 10^{-7} \mathrm{~m}^{-1} \mathrm{sr}^{-1}$ was observed. However, during this period the highest volcanic aerosol optical depth was observed at CIAO with a value of 0.12 at $355 \mathrm{~nm}$. A similar value was only observed on 20 April at 22:00 UTC.

In terms of intensive properties, there were significant differences in comparison to other cases. Lidar ratio values are in-between those observed upon the first arrival of volcanic material on 20 April and after 21 April, while Ångström exponents were smaller than the values typically observed in previous days. The mean linear depolarization ratio of $16 \%$ was similar to the one observed on 20 April.

\subsubsection{8-19 May 2010}

The last observation of volcanic particles over Potenza was recorded on 18-19 May between 2 and $5 \mathrm{~km}$ a.s.l., when there were neither restrictions on air traffic over Italy anymore nor alerts for volcanic particle arrival. On these two days, layers above $5 \mathrm{~km}$ a.s.l. were identified whose origin is still not fully clarified. For the days concerned, backtrajectories passing over continental Europe and the Atlantic Ocean do not conclusively reveal the volcanic origin of the observed particles. Since after the first explosive eruption on 15 April volcanic aerosol traces at these altitudes were indeed observed, one could potentially attribute the identified layer to volcanic particles. However, as far as this case is concerned, the lack of multi-wavelength analyses due to the sparse low clouds (about $60 \%$ of the time) and daytime conditions did not permit a reliable assignment of these layers to a certain type. Therefore these layers were labeled as aerosol of unknown type.

\subsection{Optical properties of volcanic aerosol}

The dependence of intensive particle properties (i.e. the backscatter-related Ångström exponent at 532/1064 nm, the extinction and backscatter-related Ångström exponents at $355 / 532 \mathrm{~nm}$, the lidar ratios at 355 and $532 \mathrm{~nm}$, and the linear particle depolarization ratio) on relative humidity, measured by a microwave radiometer at CIAO, was investigated (see Fig. 6). In particular, the backscatter-related Ångström exponent at $532 / 1064 \mathrm{~nm}, \stackrel{a}{a}(\beta)$ (Fig. 6a) and lidar ratio at $355 \mathrm{~nm}$, $S_{\mathrm{uv}}$ (Fig. 6c) were considered, because of the larger availability of these data respect to Ångström exponent at 532/355 nm and lidar ratio at $532 \mathrm{~nm}, S_{\text {vis }}$, respectively. The particle linear depolarization ratio at $532 \mathrm{~nm}, \delta$, is reported as a function of the relative humidity (RH) in Fig. 6b. In addition, the ratio of the lidar ratios in the UV and visible, $S_{\mathrm{uv}} / S_{\mathrm{vis}}$ is reported (Fig. 6d), since this parameter has been found to be important for the investigation of microphysical particle properties (Müller et al., 2007). 

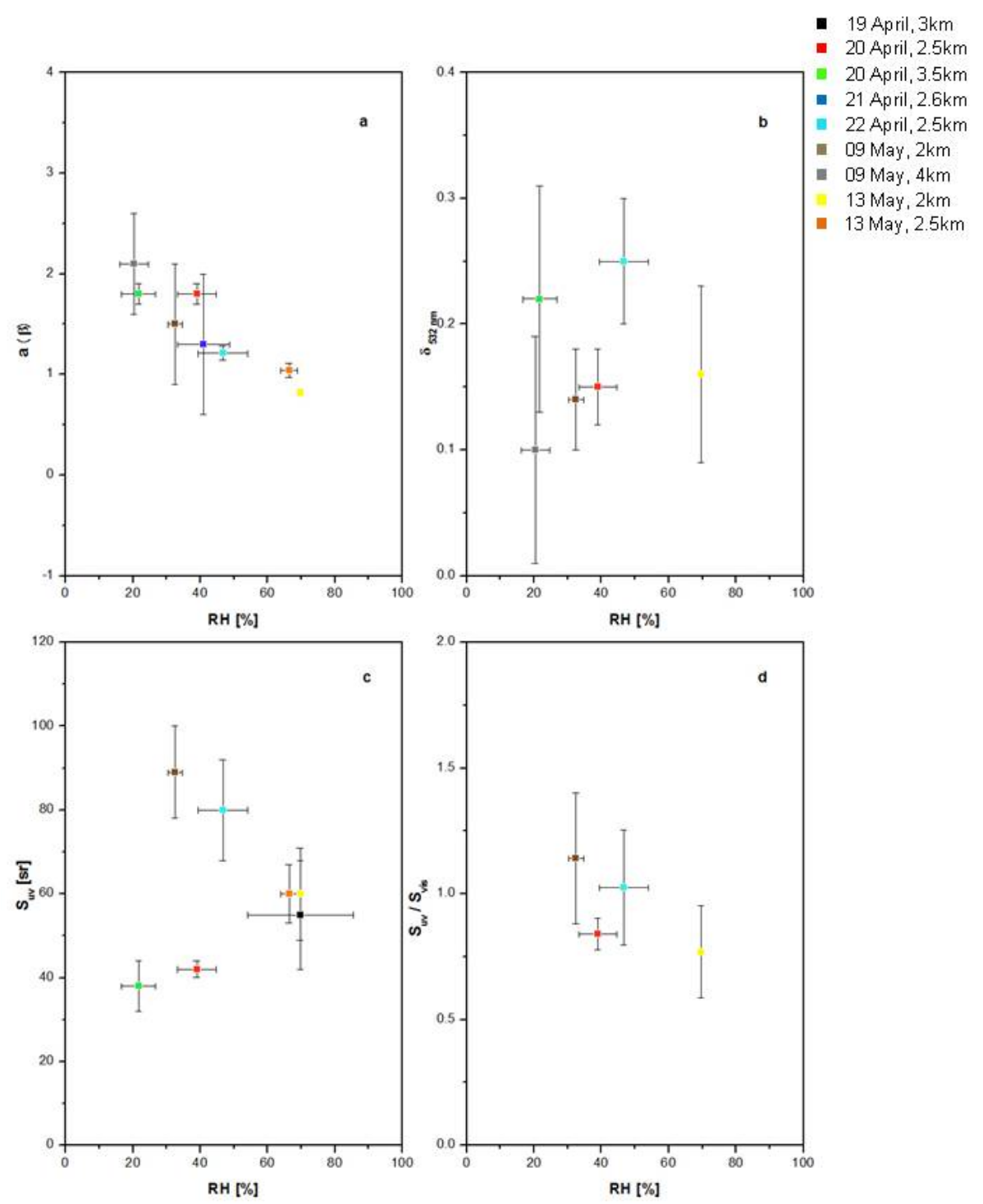

Fig. 6. Intensive properties as a function of the relative humidity, measured by the microwave profiler at CIAO. Mean values measured in the identified volcanic layers are reported. (a) Backscatter-related Ångström exponent at 532/1064 nm (̊̊( $\beta$ )); (b) particle linear depolarization ratio at $532 \mathrm{~nm}\left(\delta_{532 \mathrm{~nm}}\right)$; (c) the lidar ratio at $355 \mathrm{~nm}\left(S_{\mathrm{uv}}\right)$; (d) ratio of lidar ratios in the UV and visible $\left(S_{\mathrm{uv}} / S_{\mathrm{vis}}\right)$. Standard deviations for layers at specific altitudes are indicated by the error bars.

The decrease of $\stackrel{a}{(}(\beta)$ with increasing RH demonstrates the hygroscopic growth of particles. A similar dependence on RH was found for the ratio of lidar ratios. High $\delta$ observed in cases of high RH values could indicate the presence of sulfate aerosols (Sakai et al., 2000).

No clear RH dependence was found for $S_{\mathrm{uv}}$ : for the same $\mathrm{RH}$, low (around $40 \mathrm{sr}$ ) and high (around $85 \mathrm{sr}$ ) values of $S_{\mathrm{uv}}$ were observed. In particular, low $S_{\mathrm{uv}}$ values were measured on 20 April. The $S_{\mathrm{uv}}$ value of $54 \mathrm{sr}$ recorded for the same event on 19 April indicates an increase with RH for this specific event. According to backtrajectory analysis, the observations at CIAO on 19 and 20 April were related to the largest amount of transportable ash emitted by the volcano and the highest altitudes at which particles of volcanic origin occurred on 17-18 April (Langmann et al., 2012). Similarly, CIAO observations on 13 May were related to a further peak of transportable emitted aerosol load and maximum emission altitude occurred on 8-9 May (Langmann et al., 2012). Indeed, these days were associated with the strongest aerosol backscatter peaks, descending as a function of time as evident in time-dependent backscatter profiles. In addition, the mean value of $S_{\mathrm{uv}}$ in the volcanic layer on 13 May fits well with the $S_{\mathrm{uv}}$ dependence on RH observed on 19-20 April. This suggests differences in terms of the microphysical properties of volcanic particles reaching CIAO on 19-20 April and 13 May. A $S_{\mathrm{uv}} \approx 40 \mathrm{sr}$, increasing up to $60-70 \mathrm{sr}$ with 
Table 1. Intensive properties calculated within identified volcanic layers. Mean values and standard deviations of the lidar ratio at $355 \mathrm{~nm}$ $\left(S_{\mathrm{uv}}\right)$ and $532 \mathrm{~nm}\left(S_{\mathrm{vis}}\right)$; Ångström exponent at 355/532 nm $(\stackrel{a}{a}(\alpha))$; backscatter-related Ångström exponent at $532 / 1064 \mathrm{~nm}(\stackrel{a}{ }(\beta))$ and particle linear depolarization ratio at $532 \mathrm{~nm}(\delta)$ are reported.

\begin{tabular}{lllllll}
\hline $\begin{array}{l}\text { Time } \\
\text { (UTC) }\end{array}$ & $\begin{array}{l}\text { Altitude } \\
{[\mathrm{km} \text { a.s.1.] }}\end{array}$ & $\begin{array}{l}S_{\mathrm{uv}} \\
{[\mathrm{sr}]}\end{array}$ & $\begin{array}{l}S_{\mathrm{vis}} \\
{[\mathrm{sr}]}\end{array}$ & $\stackrel{\circ}{a}(\alpha)$ & $\stackrel{a}{ }(\beta)$ & $\delta$ \\
\hline 19 April, 19:53-20:24 & $2.1-4.2$ & $54 \pm 14$ & n.a. & n.a. & n.a. & n.a. \\
20 April, 21:00-23:05 & $2.0-3.0$ & $42 \pm 2$ & $50 \pm 3$ & $1.4 \pm 0.2$ & $1.8 \pm 0.1$ & $0.15 \pm 0.03$ \\
& $3.1-4.0$ & $38 \pm 6$ & n.a. & n.a. & $1.8 \pm 0.1$ & $0.22 \pm 0.03$ \\
21 April, 11:30-12:30 & $1.6-3.6$ & n.a. & n.a. & n.a. & $1.3 \pm 0.7$ & n.a. \\
21-22 April, 19:07-03:09 & $1.6-3.4$ & $80 \pm 12$ & $78 \pm 13$ & $1.1 \pm 0.3$ & $1.21 \pm 0.07$ & $0.25 \pm 0.05$ \\
29 April, 22:17-23:24 & $2.7-3.4$ & $80 \pm 17$ & $92 \pm 16$ & $1.4 \pm 0.3$ & $1.39 \pm 0.04$ & n.a. \\
9 May, 19:03-21:58 & $1.6-2.5$ & $89 \pm 11$ & $78 \pm 15$ & $1.03 \pm 0.07$ & $1.5 \pm 0.6$ & $0.14 \pm 0.04$ \\
& $2.5-5.0$ & n.a. & n.a. & n.a. & $2.1 \pm 0.5$ & $0.10 \pm 0.09$ \\
13 May, 20:16-21:01 & $1.5-2.3$ & $60 \pm 11$ & $78 \pm 12$ & $1.1 \pm 0.4$ & $0.82 \pm 0.03$ & $0.16 \pm 0.07$ \\
& $2.3-2.6$ & $60 \pm 7$ & n.a. & n.a. & $1.04 \pm 0.07$ & n.a. \\
\hline
\end{tabular}

increasing RH, was observed at CIAO on 19-20 April and 13 May 2010 together with a ratio of lidar ratios of about 0.8 . Lidar ratio values around $55 \mathrm{sr}$ are reported in the literature for fresh ash cases (Pappalardo et al., 2004a; Ansmann et al., 2010). This suggests the presence of some ash, besides sulfates, in agreement with higher $\stackrel{a}{a}(\beta)$ values for the same RH on these days in comparison to all other days (see Fig. 6a). Moreover, there are some indications that the aging of aerosol during the transport across the European continent could affect the ratio of lidar ratios, and hence lead to values below 1 (Müller at al., 2007).

Besides the similarities of data on 19-20 April and 13 May, which made these cases peculiar concerning other volcanic particle observations recorded at CIAO, ultra-giant particle signatures were also observed in cloud radar signals in correspondence to these two cases (Madonna et al., 2010). These signatures can be an indication of modification processes of volcanic particles. Further investigations are needed to better understand the nature of these signatures in the radar signals.

For the other cases, $S_{\mathrm{uv}}=80 \mathrm{sr}$ was obtained while the ratio of lidar ratios is greater than 1 . This could be related to more mixing between continental and sulfate aerosol, in agreement with high values for $S_{\mathrm{uv}}$, larger particles, and the values of the ratio of lidar ratios (Ansmann et al., 2011; Müller et al., 2007).

At this stage the aerosol size distribution for the cases reported in Table 1 and Fig. 6 cannot be appropriately investigated on the basis of the CIAO AERONET measurements, because only few AERONET data are available for the presence of clouds. Moreover, the Raman lidar (night-time) and AERONET (daytime) measurements are not simultaneous, and the observed high variability in the aerosol content does not permit to use AERONET inversion for further investigations of the aerosol layers identified through the lidar measurements. A study based on the integration of lidar-radar measurements, with the support of all ancillary instrumentation available at CIAO, and a numerical simulation will be carried out in order to investigate both, the aerosol size and microphysical properties of volcanic particles.

\section{Summary}

The observations of the Eyjafjallajökull volcanic cloud by multi-wavelength Raman lidar performed at CIAO observatory, in southern Italy, are presented and discussed. A methodology for the identification of the volcanic aerosol layers starting from temporal series of quality assured particle backscatter profiles is described in detail. With the support of model outputs, this methodology relies on both the multi-wavelength Raman lidar measurements and the longterm measurements performed at CIAO within EARLINET. Based on this methodology, this paper provides, for the first time, the vertical and temporal distribution of aerosol over southern Italy during the eruption, including the characterization of particle optical properties.

In the aerosol mask for the period between 19 April and 20 May five periods of volcanic aerosol occurrences are discussed: 19-22 April, 27-29 April, 8-9 May, 13-14 May and 18-19 May. Volcanic layers were observed in the whole troposphere. On 21-22 April and 13 May volcanic aerosol was even observed within the PBL. The simultaneous presence of dust and volcanic aerosol was observed both, at different altitudes, but also within the same layer where both types are able to mix.

Two optical depth maxima of approximately $0.12-0.13$ at $355 \mathrm{~nm}$ were found for volcanic aerosol over Potenza on 20 April, 22:00 UTC and 13 May, 20:30 UTC. These values are significantly lower than the peak values of ca. 0.7 at $532 \mathrm{~nm}$ observed over Leipzig (Germany) in the volcanic layer during this event (Ansmann et al., 2010) and the moderate 
columnar optical depth around $0.3-0.4$ and 0.5 observed over the Iberian peninsula (5-11 May) and Cabauw (17-21 May), respectively, for almost direct transport (Toledano et al., 2012; Ansmann et al., 2011). The low values observed at CIAO are related both to the larger distance from the Eyjafjallajökull volcano and the dispersion of the volcanic cloud during its transport across Europe.

A complete multi-wavelength analysis of the long-range transported volcanic aerosol is presented for the most interesting time-windows. The dependence of intensive properties on relative humidity is discussed. Typical values of UV lidar ratios and depolarization ratios are high and tend to increase with increasing relative humidity. The ratio of lidar ratios values are found to be greater than unity. These values suggest the presence of volcanic sulfates mixed with continental aerosol. Different intensive aerosol optical properties were measured at CIAO in correspondence of the maxima observed in the volcanic aerosol load on 19-20 April and 13 May: the UV lidar ratio increased from 40 to $70 \mathrm{sr}$ for increasing relative humidity from 20 to $70 \%$ and ratio of lidar ratio values were below 1 . Apart from the occurrence of sulfate aerosol, these values indicate also the presence of some ash which is affected by the aging during transport over Europe. A study based on the combined use of all CIAO observatory instrumentation, including lidar-radar integration, will be carried out in order to investigate the size and microphysical properties of volcanic aerosol in more detail.

In conclusion, observations of aerosol far away from their source allow the investigation of modifications of their properties and of mixing processes as they occur during the transport over the European continent. In particular, differences between volcanic aerosols and Saharan dust particles are discussed as well as the mixing of same, since both happened to occur on the same days with particles at similar altitudes. Moreover the measurements presented can be used as a reference for the testing of atmospheric dispersion models at the extremes of their operability, i.e. far away from the source and for low amounts of volcanic aerosol. Finally, the results presented in terms of aerosol layering, typing, and optical properties can be useful for comparison and integration studies with satellite observations of this volcanic event (e.g. Clarisse et al., 2010). In this context, a large geographical coverage is needed both for the quantitative validation of satellite data and the development of an integrated approach between satellite and ground-based observations. Quantitative information about the 4D distribution of volcanic plume at continental scale will be obtained applying the methodology described in this paper to all EARLINET observations of the volcanic event.
Acknowledgements. The financial support for EARLINET by the European Commission under grant RICA-025991 is gratefully acknowledged. We acknowledge the support of the European Commission through GEOmon Integrated Project under the 6th Framework Programme (contract number FP6-2005-Global-4-036677). The CIAO observatory is partially supported by the Italian Civil Protection Department of the Ministry Council.

The authors would like to thank the NOAA Air Resources Laboratory (ARL) for the provision of the HYSPLIT backtrajectory analysis; the German Weather Service for the air mass back-trajectory analysis, NILU for providing FLEXTRA back-trajectories based on meteorological data provided from ECMWF (European Centre for Medium Range Weather Forecast) which are available at http://www.nilu.no/trajectories; and Tom L. Kucsera (GEST) at NASA/Goddard for back-trajectories available at the http://aeronet. gsfc.nasa.gov website. We also thank the Barcelona Supercomputing Center for forecasts with the Dust Regional Atmospheric Model (DREAM) and the Data User Element of the European Space Agency Data for data available from "ATSR World Fire Atlas". The Eyjafjallajökull volcanic activity was monitored through updated reports provided by the Iceland Meteorological Office which are available at http://en.vedur.is/earthquakes-and-volcanism/articles/ $\mathrm{nr} / 2072$.

The authors would like to thank A. Ruth (University College Cork, Ireland) for comments on the manuscript.

Edited by: F. Prata

\section{References}

Ansmann, A., Riebesell, M., Wandinger U., Weitkamp C., Voss E., Lahmann W., and Michaelis W.: Combined Raman elasticbackscatter lidar for vertical profiling of moisture, aerosol extinction, backscatter and lidar ratio, Appl. Phys. B., 55, 18-28, 1992.

Ansmann, A., Tesche, M., Groß, S., Freudenthaler, V., Seifert, P., Hiebsch, A., Schmidt, J., Wandinger, U., Mattis, I., Müller, D., and Wiegner M.: The 16 April 2010 major volcanic ash plume over central Europe: EARLINET lidar and AERONET photometer observations at Leipzig and Munich, Germany, Geophys. Res. Lett., 37, L13810, doi:10.1029/2010GL043809, 2010.

Ansmann, A., Tesche, M., Seifert, P., Groß, S., Freudenthaler, V., Apituley, A., Wilson, K. M., Serikov, I., Linné, H., Heinold, B., Hiebsch, A., Schnell, F., Schmidt, J., Mattis, I., Wandinger, U., and Wiegner, M.: Ash and fine-mode particle mass profiles from EARLINET-AERONET observations over central Europe after the eruptions of the Eyjafjallajökull volcano in 2010, J. Geophys. Res., 116, D00U02, doi:10.1029/2010JD015567, 2011.

Böckmann, C., Wandinger, U., Ansmann, A., Bösenberg, J., Amiridis, V., Boselli,A., Delaval, A., De Tomasi, F., Frioud, M., Grigorov, I., Hågård, A., Horvat, M., Iarlori, M., Komguem, L., Kreipl, S., Larchevêque, G., Matthias, V., Papayannis, A., Pappalardo, G., Rocadenbosch, F., Rodrigues, J. A., Schneider, J., Shcherbakov, V., and Wiegner, M.: Aerosol lidar intercomparison in the framework of the EARLINET project. 2. Aerosol backscatter algorithms, Appl. Opt., 43, 977-989, 2004.

Bukowiecki, N., Zieger, P., Weingartner, E., Jurányi, Z., Gysel, M., Neininger, B., Schneider, B., Hueglin, C., Ulrich, A., Wichser, 
A., Henne, S., Brunner, D., Kaegi, R., Schwikowski, M., Tobler, L., Wienhold, F. G., Engel, I., Buchmann, B., Peter, T., and Baltensperger, U.: Ground-based and airborne in-situ measurements of the Eyjafjallajökull volcanic aerosol plume in Switzerland in spring 2010, Atmos. Chem. Phys., 11, 10011-10030, doi:10.5194/acp-11-10011-2011, 2011.

Campanelli, M., Estelles, V., Smyth, T., Tomasi, C., MartìnezLozano, M. P., Claxton, B., Muller, P., Pappalardo, G., Pietruczuk, A., Shanklin, J., Colwell, S., Wrench, C., Lupi, A., Mazzola, M., Lanconelli, C., Vitale, V., Congeduti, F., Dionisi, D., Cardillo, F., Cacciani, M., Casasanta, G., and Nakajima, T.: Monitoring of Eyjafjallajökull volcanic aerosol by the new European Skynet Radiometers (ESR) network, Atmos. Environ., 48, 33-45, doi:10.1016/j.atmosenv.2011.09.070, 2012.

Clarisse, L., Prata, F., Lacour, J.-L., Hurtmans, D., Clerbaux, C., and Coheur, P.-F.: A correlation method for volcanic ash detection using hyperspectral infrared measurements, Geophys. Res. Lett., 37, L19806, doi:10.1029/2010GL044828, 2010.

Dacre, H. F., Grant, A. L. M., Hogan, R. J., Belcher, S. E., Thomson, D. J., Devenish, B. J., Marenco, F., Hort, M. C., Haywood, J. M., Ansmann, A., Mattis, I., and Clarisse, L.: Evaluating the structure and magnitude of the ash plume during the initial phase of the 2010 Eyjafjallajökull eruption using lidar observations and NAME simulations, J. Geophys. Res., 116, D00U03, doi:10.1029/2011JD015608, 2011.

Di Girolamo, P., Ambrico, P. F., Amodeo, A., Boselli, A., Pappalardo, G., and Spinelli, N.: Aerosol observations by lidar in the nocturnal boundary layer, Appl. Opt., 38, 4585-4595, 1999.

Draxler, R. R. and Rolph, G. D.: HYSPLIT (HYbrid Single-Particle Lagrangian Integrated Trajectory) Model access via NOAA ARL READY Website (http://ready.arl.noa.gov/HYSPLIT. php), NOAA Air Resources Laboratory, Silver Spring, MD, 2011.

Emeis, S., Forkel, R., Junkermann, W., Schäfer, K., Flentje, H., Gilge, S., Fricke, W., Wiegner, M., Freudenthaler, V., Groß, S., Ries, L., Meinhardt, F., Birmili, W., Münkel, C., Obleitner, F., and Suppan, P.: Measurement and simulation of the 16/17 April 2010 Eyjafjallajkull volcanic ash layer dispersion in the northern Alpine region, Atmos. Chem. Phys., 11, 2689-2701, doi:10.5194/acp-11-2689-2011, 2011.

Flentje, H., Claude, H., Elste, T., Gilge, S., Köhler, U., PlassDülmer, C., Steinbrecht, W., Thomas, W., Werner, A., and Fricke, W.: The Eyjafjallajökull eruption in April 2010 - detection of volcanic plume using in-situ measurements, ozone sondes and lidar-ceilometer profiles, Atmos. Chem. Phys., 10, 1008510092, doi:10.5194/acp-10-10085-2010, 2010.

Freudenthaler, V., Esselborn, M., Wiegner, M., Heese, B., Tesxhe, M., Ansmann, A., Müller, D., Althausen, D., Wirth, M., Fix, A., Ehret, G., Knippertz, P., Toledano, C., Gasteiger, J., Garhammer, M., and Seefeldner, M.: Depolarization ratio profiling at several wavelengths in pure Saharan dust during SAMUM 2006, Tellus B, 61, 165-179, 10.1111/j.1600-0889.2008.00396.x, 2009.

Gasteiger, J., Groß, S., Freudenthaler, V., and Wiegner, M.: Volcanic ash from Iceland over Munich: mass concentration retrieved from ground-based remote sensing measurements, Atmos. Chem. Phys., 11, 2209-2223, doi:10.5194/acp-11-22092011, 2011.

Heinold, B., Tegen, I., Wolke, R., Ansmann, A., Mattis, I., Minikin, A., Schumann, U., and Weinzierl, B.: Simulations of the 2010 Eyjafjallajökull volcanic ash dispersal over Europe using COSMO-MUSCAT, Atmos. Environ., 48, 195-204, doi:10.1016/j.atmosenv.2011.05.021, 2012.

Hervo, M., Quennehen, B., Kristiansen, N. I., Boulon, J., Stohl, A., Fréville, P., Pichon, J.-M., Picard, D., Labazuy, P., Gouhier, M., Roger, J.-C., Colomb, A., Schwarzenboeck, A., and Sellegri, K.: Physical and optical properties of 2010 Eyjafjallajkull volcanic eruption aerosol: ground-based, Lidar and airborne measurements in France, Atmos. Chem. Phys., 12, 1721-1736, doi:10.5194/acp-12-1721-2012, 2012.

Langmann, B., Folch, A., Hensch, M., and Matthias, V.: Volcanic ash over Europe during the eruption of Eyjafjallajökull on Iceland, April-May 2010, Atmos. Environ., 48, 97-103, doi:10.1016/j.atmosenv.2011.05.037, 2012.

Lettino, A., Caggiano, R., Fiore, S., Macchiato, M., Sabia, S., and Trippetta S.: Eyjafjallajökull volcanic ash in southern Italy, Atmos. Environ. , 48, 97-103, doi:10.1016/j.atmosenv.2011.05.037, 2011.

Liu, Z., Kuehn, R., Vaughan, M., Winker, D., Omar, A., Powell, K., Trepte, C., Hu, Y., and Hosttler, C.: The CALIPSO cloud and aerosol discrimination: version 3 algorithm and test results - Proceedings of the 25th International Laser Radar Conference, 1245-1248, St. Petersburg, Russia, 5-9 July 2010, 2010.

Madonna, F., Amodeo, A., D’Amico, G., Mona, L., and Pappalardo, G.: Observation of non-spherical ultragiant aerosol using a microwave radar, Geophys. Res. Lett., 37, L21814, doi:10.1029/2010GL044999, 2010.

Madonna, F., Amodeo, A., Boselli, A., Cornacchia, C., Cuomo, V., D’Amico, G., Giunta, A., Mona, L., and Pappalardo, G.: CIAO: the CNR-IMAA advanced observatory for atmospheric research, Atmos. Meas. Tech., 4, 1191-1208, doi:10.5194/amt4-1191-2011, 2011.

Markowicz, K. M., Zielinski, T., Pietruczuk, A., Posyniak, M., Zawadzka, O., Makuch, P., Stachlewska, I. S., Jagodnicka, A. K., Petelski, T., Kumala, W., Sobolewski, P., and Stacewicz, T.: Remote sensing measurements of the volcanic ash plume over Poland in April 2010, Atmos. Environ., 48, 66-75, doi:10.1016/j.atmosenv.2011.07.015, 2012.

Matthias, V., Balis, D., Bösenberg, J., Eixmann, R., Iarlori, M., Komguem, L., Mattis, I., Papayannis, A., Pappalardo, G., Perrone, M. R., and Wang, X.: The vertical aerosol distribution over Europe: statistical analysis of Raman lidar data from 10 EARLINET stations, J. Geophys. Res., 109, D18201, doi:10.1029/2004JD004638, 2004.

Matthias, V., Aulingera, A., Biesera, J., Cuesta, J., Geyera, B., Langmanne, B., Serikov, I., Mattis, I., Minikin, A., Mona, L., Quante, M., Schumann, U., and Weinzierl, B.: The ash dispersion over Europe during the Eyjafjallajökull eruption - comparison of CMAQ simulations to remote sensing and in-situ observations, Atmos. Environ., 48, 184-194, doi:10.1016/j.atmosenv.2011.06.077, 2012.

Mona, L., Amodeo, A., D’ Amico, G., Pandolfi, M., and Pappalardo, G.: Lidar ratio climatology: 5 years of systematic Raman lidar measurements over Potenza, Italy - 23rd International Laser Radar Conference, Nara Japan, 24-28 July 2006, vol. 1, 321324, 2006a.

Mona, L., Amodeo, A., Pandolfi, M., and Pappalardo, G.: Saharan dust intrusions in the Mediterranean area: Three years of Raman lidar measurements, J. Geophys. Res., 111, D16203, 
doi:10.1029/2005JD006569, 2006b.

Mona, L., Cornacchia, C., D’Amico, G., Di Girolamo, P., Pappalardo, G., Pisani, G., Summa, D., Wang, X., and Cuomo, V.: Characterization of the variability of the humidity and cloud fields as observed from a cluster of ground-based lidar systems, Q. J. Roy. Meteorol. Soc., 133, 257-271, 2007.

Mona, L., Pappalardo, G., Amodeo, A., D’Amico, G., Madonna, F., Boselli, A., Giunta, A., Russo, F., and Cuomo, V.: One year of CNR-IMAA multi-wavelength Raman lidar measurements in coincidence with CALIPSO overpasses: Level 1 products comparison, Atmos. Chem. Phys., 9, 7213-7228, doi:10.5194/acp-97213-2009, 2009.

Morille, Y., Haeffelin, M., Drobinski, P., and Pelon, J.: STRAT: An Automated Algorithm to Retrieve the Vertical Structure of the Atmosphere from Single-Channel Lidar Data, J. Atmos. Ocean. Tech., 24, 761-775, 2007.

Müller, D., Ansmann, A., Mattis, I., Tesche, M., Wandinger, U., Althausen, D., and Pisani, G.: Aerosol-type-dependent lidar ratio observed with Raman lidar, J. Geophys. Res., 112, D16202, doi:10.1029/2006JD008292, 2007.

Müller, D., Heinold, B., Tesche, M., Tegen, I., Althausen, D., Alados, Arboledas, L., Amiridis, V., Amodeo, A., Ansmann, A., Balis, D., Comeron, A., D’Amico, G., Gerasopoulos, E., Guerrero-Rascado, J. L., Freudenthaler, V., Giannakaki, E., Heese, B., Iarlori, M., Knippertz, P., Mamouri, R. E., Mona, L., Papayannis, A., Pappalardo, G., Perrone, R.-M., Pisani, G., Rizi, V., Sicard, M., Spinelli, N., Tafuro, A., and Wiegner, M.: EARLINET observations of the 14-22-May long-range dust transport event during SAMUM 2006: validation of results from dust transport modelling, Tellus, 61B, 325-339, 2009.

O'Dowd, C., Ceburnis, D., Ovadnevaite, J., Martucci, G., Bialek, J., Monahan, C., Berresheim, H., Vaishya, A., Grigas, T., Jennings, S. G., McVeigh, P., Varghese, S., Flanagan, R., Martin, D., Moran, E., Lambkin, K., Semmler, T., Perrino, C., and McGrath, R.: The Eyjafjallajökull ash plume - Part I: Physical, chemical and optical characteristics, Atmos. Environ., 48, 129-142, doi:10.1016/j.atmosenv.2011.07.004, 2012.

Papayannis, A., Amiridis, V., Mona, L., Tsaknakis, G., Balis, D., Bösenberg, J., Chaikovski, A., De Tomasi, F., Grigorov, I., Mattis, I., Mitev, V., Müller, D., Nickovic, S., Pérez, C., Pietruczuk, A., Pisani, G., Ravetta, F., Rizi, V., Sicard, M., Trickl, T., Wiegner, M., Gerding, M., D’Amico, G., and Pappalardo, G.: Systematic lidar observations of aerosol optical properties during Saharan dust intrusions over Europe, in the frame of EARLINET (2000-2002): Statistical analysis and results, J. Geophys. Res., 113, D10204, doi:10.1029/2007JD009028, 2008.

Papayannis, A., Mamouri, R. E., Amiridis, V., Giannakaki, E., Veselovskii, I., Kokkalis, P., Tsaknakis, G., Balis, D., Kristiansen, N. I., Stohl, A., Korenskiy, M., Allakhverdiev, K., Huseyinoglu, M. F., and Baykara, T.: Optical properties and vertical extension of aged ash layers over the Eastern Mediterranean as observed by Raman lidars during the Eyjafjallajökull eruption in May 2010, Atmos. Environ., 48, 56-65, doi:10.1016/j.atmosenv.2011.08.037, 2012.

Pappalardo, G., Amodeo, A., Mona, L., Pandolfi, M., Pergola, N., and Cuomo, V.: Raman lidar observations of aerosol emitted during the 2002 Etna eruption, Geophys. Res. Lett., 31, L05120, doi:10.1029/2003GL019073, 2004a.

Pappalardo, G., Amodeo, A., Pandolfi, M., Wandinger, U., Ans- mann, A., Bosenberg, J., Matthias, V., Amiridis, V., De Tomasi, F., Frioud, M., Iarlori, M., Komguem, L., Papayannis, A., Rocadenbosch, F., and Wang, X.: Aerosol lidar intercomparison in the framework of the EARLINET project. 3. Raman lidar algorithm for aerosol extinction, backscatter and lidar ratio, Appl. Opt., 43, 5370-5385, 2004b.

Pappalardo, G., Amodeo, A., Ansmann, A., Apituley, A., Alados Arboledas, L., Balis, D., Böckmann, C., Chaikovsky, A., Comeron, A., D'Amico, G., De Tomasi, F., Freudenthaler, V., Giannakaki, E., Giunta, A., Grigorov, I., Gustafsson, O., Gross, S., Haeffelin, M., Iarlori, M., Kinne, S., Linné, H., Madonna, F., Mamouri, R., Mattis, I., McAuliffe, M., Molero, F., Mona, L., Müller, D., Mitev, V., Nicolae, D., Papayannis, A., Perrone, M. R., Pietruczuk, A., Pujadas, M., Putaud, J.-P., Ravetta, F., Rizi, V., Serikov, I., Sicard, M., Simeonov, V., Spinelli, N., Stebel, K., Trickl, T., Wandinger, U., Wang, X., Wagner, F., and Wiegner, M.: EARLINET observations of the Eyjafjallajökull ash plume over Europe, in: Lidar Technologies, Techniques, and Measurements for Atmospheric Remote Sensing VI, Proceedings of SPIE, SPIE Remote Sensing 2010, Toulouse, 20-23 September 2010, vol: 7832, 78320-78328, 2010a.

Pappalardo, G., Amodeo, A., Ansmann, A., Apituley, A., Alados Arboledas, L., Balis, D., Böckmann, C., Chaikovsky, A., Comeron, A., D’Amico, G., De Tomasi, F., Freudenthaler, V., Giannakaki, E., Giunta, A., Grigorov, I., Gustafsson, O., Gross, S., Haeffelin, M., Iarlori, M., Kinne, S., Linné, H., Madonna, F., Mamouri, R., Mattis, I., McAuliffe, M., Molero, F., Mona, L., Müller, D., Mitev, V., Nicolae, D., Papayannis, A., Perrone, M. R., Pietruczuk, A., Pujadas, M., Putaud, J.-P., Ravetta, F., Rizi, V., Serikov, I., Sicard, M., Simeonov, V., Spinelli, N., Stebel, K., Trickl, T., Wandinger, U., Wang, X., Wagner, F., and Wiegner, M.: Dispersion and evolution of the Eyjafjallajökull ash plume over Europe: vertically resolved measurements with the European LIDAR network EARLINET, 7th European Geosciences Union (EGU) General Assembly 2010, Vienna, Austria, 2-7 May 2010, EGU2010-15731, 2010b.

Pappalardo, G., Wandinger, U., Mona, L., Hiebsch, A., Mattis, I., Amodeo, A., Ansmann, A., Seifert, P., Linné, H., Apituley, A., Alados Arboledas, L., Balis, D., Chaikovsky, A., D’Amico, G., De Tomasi, F., Freudenthaler, V., Giannakaki, E., Giunta, A., Grigorov, I., Iarlori, M., Madonna, F., Mamouri, R.-E., Nasti, L., Papayannis, A., Pietruczuk, A., Pujadas, M., Rizi, V., Rocadenbosch, F., Russo, F., Schnell, F., Spinelli, N., Wang, X., and Wiegner, M.: EARLINET correlative measurements for CALIPSO: First intercomparison results, J. Geophys. Res., 115, D00H19, doi:10.1029/2009JD012147, 2010c.

Petersen, G. N.: A short meteorological overview of the Eyjafjallajökull eruption 14 April-23 May 2010, Weather, 65, 203-207, doi:10.1002/wea.634, 2010.

Sakai, T., Shibata, T., Kwon, S., Kim, Y., Tamura, K., and Iwasaka, Y.: Free tropospheric aerosol backscatter, depolarization ratio, and relative humidity measured with the Raman lidar at Nagoya in 1994-1997: contributions of aerosols from the Asian Continent and the Pacific Ocean, Atmos. Environ., 34, 431-442, 2000.

Schoeberl, M. R. and Newman, P. A.: A multiple-level trajectory analysis of vortex filaments, J. Geophys. Res., 100, 2580125816, 1995.

Schumann, U., Weinzierl, B., Reitebuch, O., Schlager, H., Minikin, A., Forster, C., Baumann, R., Sailer, T., Graf, K., Mannstein, 
H., Voigt, C., Rahm, S., Simmet, R., Scheibe, M., Lichtenstern, M., Stock, P., Rüba, H., Schäuble, D., Tafferner, A., Rautenhaus, M., Gerz, T., Ziereis, H., Krautstrunk, M., Mallaun, C., Gayet, J.-F., Lieke, K., Kandler, K., Ebert, M., Weinbruch, S., Stohl, A., Gasteiger, J., Groß, S., Freudenthaler, V., Wiegner, M., Ansmann, A., Tesche, M., Olafsson, H., and Sturm, K.: Airborne observations of the Eyjafjalla volcano ash cloud over Europe during air space closure in April and May 2010, Atmos. Chem. Phys., 11, 2245-2279, doi:10.5194/acp-11-2245-2011, 2011.

Steyn, D., Baldi, G. M., and Hoff, R. M.: The Detection of Mixed Layer Depth and Entrainment Zone Thickness from Lidar Backscatter Profiles, J. Atmos. Ocean. Tech., 16, 953-959, doi:10.1175/1520-0426(1999)016<0953:TDOMLD>2.0.CO;2, 1999.

Stohl, A.: Computation, accuracy and applications of trajectories a review and bibliography, Atmos. Environ., 32, 947-966, 1998.

Stohl, A., Wotawa G., Seibert P., and Kromp-Kolb H.: Interpolation errors in wind fields as a function of spatial and temporal resolution and their impact on different types of kinematic trajectories, J. Appl. Meteor., 34, 2149-2165, 1995.

Stohl, A., Prata, A. J., Eckhardt, S., Clarisse, L., Durant, A., Henne, S., Kristiansen, N. I., Minikin, A., Schumann, U., Seibert, P., Stebel, K., Thomas, H. E., Thorsteinsson, T., Tørseth, K., and Weinzierl, B.: Determination of time- and height-resolved volcanic ash emissions and their use for quantitative ash dispersion modeling: the 2010 Eyjafjallajökull eruption, Atmos. Chem. Phys., 11, 4333-4351, doi:10.5194/acp-11-4333-2011, 2011.
Toledano, C., Bennouna, Y., Cachorro, V., Ortiz de Galisteo, J. P., Stohl, A., Stebel, K., Kristiansen, N. I., Olmo, F. J., Lyamani, H., Obregón, M. A., Estellés, V., Wagner, F., Baldasano, J. M., González-Castanedo, Y., Clarisse, L., and de Frutos, A. M.: Aerosol, properties derived from Sun photometer and satellite observations of the Eyjafjallajökull ashes over the Iberian Peninsula, Atmos. Environ., 48, 22-32, 2012.

Vaughan, M., Young, S., Winker, D., Powell, K., Omar, A., Liu, Z., Hu, Y., and Hostetler, C.: Fully automated analysis of spacebased lidar data: an overview of the CALIPSO retrieval algorithms and data products, in: Laser Radar Techniques for Atmospheric Sensing, Proceedings of SPIE, SPIE 2004, Bellingham, WA, USA, Vol. 5575, doi:10.1117/12.572024, 2004.

Villani, M. G., Mona, L., Maurizi, A., Pappalardo, G., Tiesi, A., Pandolfi, M., D'Isidoro, M., Cuomo, V., and Tampieri, F.: Transport of volcanic aerosol in the troposphere: the case study of the 2002 Etna plume, J. Geophys. Res., 111, D21102, doi:10.1029/2006JD007126, 2006.

Wang, L. and Sassen, K.: Wavelet Analysis of Cirrus Multiscale Structures from Lidar Backscattering: A Cirrus Uncinus Complex Case Study, J. Appl. Meteorol. Climatol., 47, 2645-2658, doi:10.1175/2008JAMC1788.1, 2008. 